\title{
Percutaneous cholecystostomy in the treatment of acute calculous cholecystitis in elderly patients with COVID-19 and high comorbidity
}

\author{
(1) Çağlayan Çakır, M.D., ${ }^{1}$ 이 Hamit Ahmet Kabuli, M.D. ${ }^{2}$
}

\begin{abstract}
1'Department of Radiology, Healts Sciences University, Bakirköy Dr. Sadi Konuk Training and Resarch Hospital, İstanbul-Turkey ${ }^{2}$ Department of General Surgery, Healts Sciences University, Bakirköy Dr. Sadi Konuk Training and Resarch Hospital, İstanbul-Turkey
\end{abstract}

\begin{abstract}
BACKGROUND: The purpose of the study was to review the efficacy, safety, and outcomes of percutaneous cholecystostomy (PC) in elderly patients with acute calculous cholecystitis (ACC), high comorbidity, and COVID-19.

METHODS: The hospital registry data were examined of patients aged $>65$ years who were diagnosed with ACC and COVID-19 between March 2020 and June 2020 and who underwent PC treatment in the interventional radiology unit.

RESULTS: A total of 18 patients were diagnosed with ACC and COVID-19, then underwent PC. The patients comprised I4 (78\%) males and $4(22 \%)$ females with an average age of 73.4 years (range, 67-8I years). In 17 (94\%) patients, symptoms associated with acute cholecystitis decreased within $48-72 \mathrm{~h}$ of the PC treatment and a clinical improvement was determined. The success rate of PC was $100 \%$ and no complications. In 3 (16.6\%) patients followed up with intubation in intensive care after the procedure, mortality developed due to COVID-19-associated pneumonia and subsequent acute respiratory distress syndrome, and I5 (83.4\%) patients were discharged with an elective cholecystectomy plan.
\end{abstract}

CONCLUSION: COVID-19 infection can be fatal especially in patients over 65 years of age due to additional comorbidities. PC treatment, which can be performed under local anesthesia as a minimally invasive procedure, is an alternative treatment option in this patient group. PC can also act as a bridge in transition to elective surgery in this process management.

Keywords: Acute calculous cholecystitis; COVID-19; high-risk patients; percutaneous cholecystostomy.

\section{INTRODUCTION}

A new coronavirus (2019) appeared in humans for the $I^{\text {st }}$ time in the world in December 2019 and the disease caused by the virus infection was named COVID-19. The first cases were officially recorded in Turkey on March II, 2020. COVID-19 is a highly contagious respiratory disease, with the main clinical symptoms of fever, dry cough, fatigue, muscle pain, and shortness of breath. ${ }^{[1]}$

Acute calculous cholecystitis (ACC) is one of the most common surgical emergencies encountered today, which presents with an acute abdomen picture. The coexistence of COVID-19 and ACC is very rare.
Conservative methods, percutaneous cholecystostomy (PC), and surgery can be applied in the treatment of ACC. The main factors used to determine the treatment method are the patient's age, comorbidities, and associated American Association of Anesthesiologists-Physical Condition Classification (ASA-PS) scores, acute cholecystitis (AC) severity index, and the time between the onset of the event and the application.

The main treatment method in patients suitable for surgery is early laparoscopic cholecystectomy. The recommended treatment options are determined according to the degree of AC severity in the Tokyo guidelines revised in 2018. ${ }^{[2]}$ Early laparoscopic cholecystectomy in the patient group without low-risk comorbidities is the first option in treatment. Con-

Cite this article as: Çakır Ç, Kabuli HA. Percutaneous cholecystostomy in the treatment of acute calculous cholecystitis in elderly patients with COVID-19 and high comorbidity. Ulus Travma Acil Cerrahi Derg 2021;27:296-302.

Address for correspondence: Çağlayan Çakır, M.D.

SBÜ İstanbul Bakırköy Dr. Sadi Konuk Eğitim ve Araştırma Hastanesi, Radyoloji Anabilim Dalı, 354I0 İstanbul, Turkey

Tel: +90 212 - 414717 E-mail: drcakir1983@gmail.com

Ulus Travma Acil Cerrahi Derg 2021;27(3):296-302 DOI: 10.14744/tjtes.2020.23255 Submitted: 22.06.2020 Accepted: II.I2.2020

Copyright 2021 Turkish Association of Trauma and Emergency Surgery 
servative treatment and/or PC becomes more prominent with the laparoscopy experience of the center, and depending on the patient's condition, should still be performed early in those at high risk and with increased comorbidities. ${ }^{[3]}$

However, laparoscopic surgery and endoscopic procedures are not recommended in case of suspicion or diagnosis of COVID-19 disease. ${ }^{[4]}$

For elderly patients in this series, it was thought that the risk of perioperative morbidity and mortality may increase due to low reserves and high comorbidities, in addition to the COVID-19 diagnosis or suspicion. The aim of this study was to review the effectiveness, reliability, and outcomes of PC in elderly patients ( $\geq 65$ years) diagnosed with COVID- 19.

\section{MATERIALS AND METHODS}

This study was approved by the ethics committee of Bakirkoy Dr Sadi Konuk Education and Research Hospital (approval number: 2020/443). A retrospective scan was made of the hospital registry system, and from a total of 24 patients applied with $\mathrm{PC}$ treatment for $\mathrm{AC}$ in the interventional radiology unit between March 2020 and June 2020, 18 patients were identified who were over 65 years old and were diagnosed with ACC and COVID-19.

The diagnosis of ACC was made based on the 2013 criteria of the Tokyo guideline. ${ }^{[5]}$ These criteria were as follows: (I) Murphy sign positivity or right upper quadrant pain as a sign of local inflammation, (2) fever with systemic signs of inflammation or elevated C-reactive protein or white blood cell count, and (3) characteristic radiological findings of ACC. The patients who met all three of these criteria were included in the study.

Patients diagnosed with choledocholithiasis, pancreatitis, and gallbladder or biliary tract on first presentation were excluded from the study.
Table I. The Tokyo 2018 severity grading for AC

\section{Mild (Grade I) AC:}

Grade I can also be defined as AC in a healthy patient with no organ dysfunction and only mild inflammatory changes in the gallbladder, making cholecystectomy a safe and low-risk operative procedure.

\section{Moderate (Grade II) AC:}

"Moderate" AC is accompanied by anyone of the following conditions:

I. Elevated WBC count ( $\left.>18.000 / \mathrm{mm}^{3}\right)$.

2. Palpable tender mass in the right upper abdominal quadrant

3. Duration of complaints $>72$ ha

4. Marked local inflammation (biliaryperitonitis, pericholecystic abscess, hepatic abscess, gangrenous cholecystitis, emphysematous cholecystitis)

a: Laparoscopic surgery in AC should be performed within $96 \mathrm{~h}$ after the onset (level $2 b-4$ )

\section{Severe (Grade III) AC:}

"Severe" acutecholecystitis is accompaniedbydysfunctions in anyone of thefollowingorgans/systems

I. Cardiovasculardysfunction (hypotension requiring treatment with dopamine $\geq 5 \mu \mathrm{g} / \mathrm{kg} / \mathrm{min}$, oranydose of norepinephrine)

2. Neurologicaldysfunction (decreasedlevel of consciousness)

3. Respiratorydysfunction $\left(\mathrm{PaO}_{2} / \mathrm{FiO}_{2}\right.$ ratio $\left.<300\right)$

4. Renal dysfunction: (oliguria, creatinine $>2.0 \mathrm{mg} / \mathrm{dl}$ )

5. Hepaticdysfunction (PT-INR >I.5)

6. Hematologicaldysfunction (plateletcount $<100.000 \mathrm{~mm}^{3}$ ).

AC: Acute cholecystitis; INR: International normalized ratio.

Cholelithiasis, gallbladder wall thickening ( $>5 \mathrm{~mm}$ ) fluid, and positive sonographic Murphy findings were detected in the ultrasonography (US) examination of all the patients. In addition,

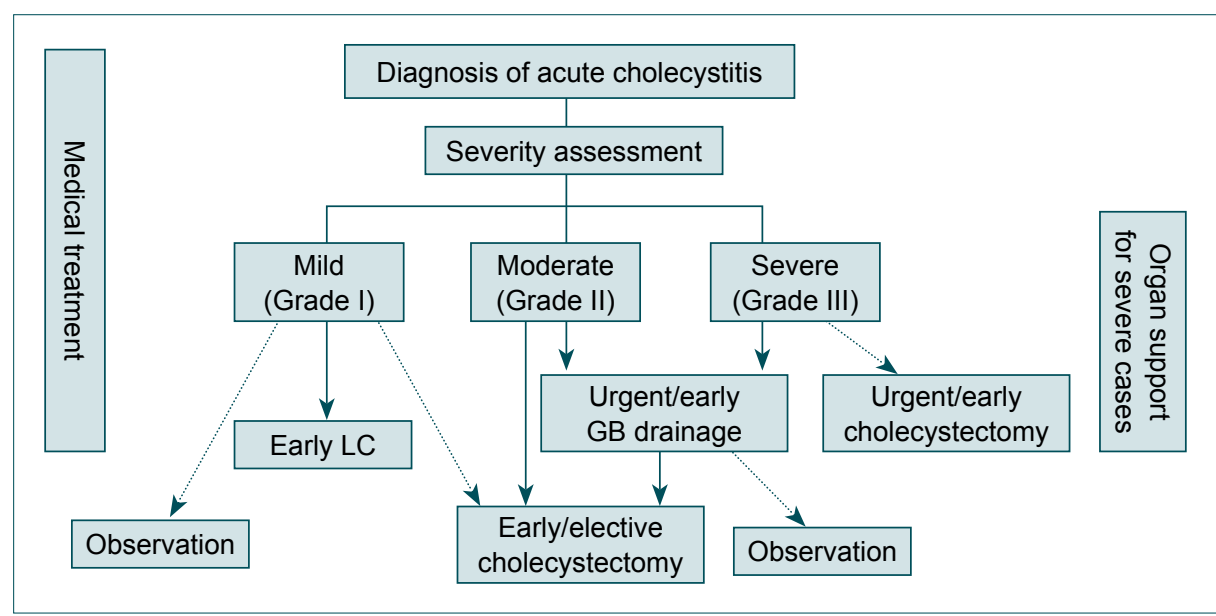

Figure 1. Management of acute cholecystitis according to the Tokyo 2018 guidelines. GB: Gallbladder; LC: Laparoscopic cholecystectomy. 
IV contrast abdominal computed tomography (CT) tests were performed on all patients to evaluate possible complications (gallbladder perforation, acute pancreatitis, malignancy, etc.).

The Tokyo 2018 Guidelines classify the severity of AC into three grades in Table I and flowcharts for the management of $A C$ are shown in Figure I. Antibiotic treatment was started after the PC procedure for ACC. According to the hemogram and hemorrhage parameters, fresh frozen plasma was administered to patients with a high international normalized ratio value, and for patients with low platelet values, PC was performed after normal values were obtained.

For the PC procedure applied in the interventional radiology unit, the patients were accepted as a high-risk group in terms of COVID-19, so double gloves, protective overshoes, and disposable surgical gowns were worn in addition to N95 mask, surgical cap, and face shield.

All procedures were performed under local anesthesia, with the Seldinger method, using a US-transhepatic or transperitoneal approach to place a lock pigtail $10 \mathrm{Fr}$ catheter into the gallbladder. The first sample was sent to the microbiology department. After the PC procedure, the patients were followed up with daily drainage and clinical observation.

\section{RESULTS}

A total of 18 patients, diagnosed with ACC with COVID-19, underwent PC. The patients comprised 14 (78\%) males and $4(22 \%)$ females with an average age of 73.4 years (range, $67-81$ years). The technical success was $100 \%$ and all of the patients were treated using the Seldinger technique under US guidance. No procedural mortality was observed.

Ten (55.6\%) patients were evaluated as ASA III, 6 (33.3\%) as ASA IV, and 2 (II.I\%) as ASA V due to existing comorbidities. The comorbid diseases and clinical follow-up processes of the patients are summarized in Table 2. According to Tokyo 2018 guidelines, 3 (16.7\%) patients were evaluated as mild, 9 (50\%) patients as moderate, and $6(33.3 \%)$ patients as severe AC.

The patients did not have any respiratory symptoms at the time of admission. At the stage of diagnosis, thorax

Table 2. Clinical details, treatment, and outcome of patients

\begin{tabular}{|c|c|c|c|c|c|c|c|c|c|c|}
\hline \multirow{2}{*}{$\begin{array}{l}\text { Patient } \\
\text { No./Sexl } \\
\text { Age } \\
\text { (years) }\end{array}$} & \multirow{2}{*}{$\begin{array}{l}\text { ASA-PC } \\
\text { Score }\end{array}$} & \multicolumn{5}{|c|}{ Comorbidity } & \multirow{2}{*}{$\begin{array}{l}\text { COVID-I9 } \\
\text { (RTPCR) } \\
\text { Test }\end{array}$} & \multirow{2}{*}{$\begin{array}{c}\text { Pre-interventional } \\
\text { CRP (mg/L) and } \\
\text { leukocyte count } \\
\left(10^{3} / \mu \mathrm{l}\right)\end{array}$} & \multirow{2}{*}{$\begin{array}{l}\text { Length } \\
\text { of } \\
\text { stay } \\
\text { (days) }\end{array}$} & \multirow[t]{2}{*}{ Outcome } \\
\hline & & Diabetes & Hypertension & $\begin{array}{l}\text { Congestive } \\
\text { heart } \\
\text { failure }\end{array}$ & $\begin{array}{l}\text { Chronic } \\
\text { kidney } \\
\text { failure }\end{array}$ & COPD & & & & \\
\hline I/M/75 & 4 & + & + & + & & & + & $|30 / 2|$ & 24 & Death \\
\hline $2 / M / 67$ & 3 & + & & & & & + & $126 / 11$ & 4 & Discharged \\
\hline $3 / M / 73$ & 4 & & + & & + & & + & $38 / 18$ & 32 & Discharged \\
\hline 4/M/8I & 5 & + & + & + & + & + & + & $231 / 15$ & 3 & Death \\
\hline $5 / F / 8 I$ & 3 & + & + & & & & + & $52 / 15$ & 5 & Discharged \\
\hline $6 / \mathrm{M} / 67$ & 3 & + & + & & & & & $42 / 11$ & 4 & Discharged \\
\hline 7/M/70 & 3 & + & + & + & & & + & $28 / 11$ & 21 & Discharged \\
\hline 8/F/79 & 3 & + & + & + & & & + & $14 / 18$ & 10 & Discharged \\
\hline $9 / M / 68$ & 4 & + & + & & & & & $|4 /| \mid$ & 3 & Discharged \\
\hline I0/M/74 & 4 & + & + & & & & + & $16 / 11$ & 28 & Discharged \\
\hline II/M/68 & 3 & + & & & + & & & $23 / 14$ & 3 & Discharged \\
\hline I2/M/70 & 4 & & + & + & + & & & $41 / 13$ & 18 & Discharged \\
\hline |3/M/8| & 5 & + & + & + & & + & + & $307 / 19$ & 13 & Death \\
\hline |4/M/8| & 3 & & + & + & & & & $42 / 15$ & 5 & Discharged \\
\hline I5/M/67 & 3 & + & & & & & & $185 / 15$ & 4 & Discharged \\
\hline I6/M/73 & 3 & + & + & + & & & & $50 / 11$ & 6 & Discharged \\
\hline I7/F/79 & 3 & + & + & + & & & & $33 / 18$ & 10 & Discharged \\
\hline I8/M/68 & 4 & & + & & & & & $22 / 12$ & 3 & Discharged \\
\hline
\end{tabular}

ASA-PC: American Association of Anesthesiologists-Physical Condition Classification; RTPCR: Reverse transcriptase-polymerase chain reaction; COPD: Chronic ob-

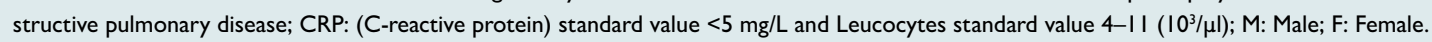


CT was applied because of the risk factors of age $>65$ years and comorbidities (diabetes, hypertension, congestive heart failure, chronic kidney failure, and chronic obstructive pulmonary disease [COPD]). The findings were found to be significant in terms of COVID-19, and from nasal and pharyngeal swabs, 9//8 patients were diagnosed with COVID-1 9 using the timed reverse transcriptase-polymerase chain reaction (RTPCR) test. The RTPCR test was negative in nine patients and although there were no respiratory symptoms, medical treatment was started with the consultation of the infectious diseases specialist due to COVID-19-positive radiological findings and the presence of comorbidities.

Symptoms associated with AC decreased within 48-72 $\mathrm{h}$ and clinically improved in 17 (94\%) patients. There were no major complications associated with the PC procedure.

A total of 26 bacterial strains were isolated in bile samples obtained from 18 patients. Pseudomonas aeruginosa was the most common bacterium growing in the bile sample cultures of the patients, and one-third of the samples were polymicrobial. COVID-19 was not determined in any of the bile sample cultures.

Follow-up in the intensive care unit with intubation was required by 3 (16.6\%) patients, and mortality developed in these 3 patients due to COVID-19-associated organizing pneumonia and acute respiratory distress syndrome (ARDS). While under clinical follow-up, catheter dislocation occurred in two patients, and after antibiotic prophylaxis applied under local anesthesia under standard sterile conditions, the catheters were reinstalled under fluoroscopy guidance. No additional interventional radiological procedure was applied to any patient. The average follow-up period for all the patients was 4 months (between 2 and 5 months). Elective cholecystectomy was performed in 5 (27.7\%) patients.

\section{DISCUSSION}

The newly discovered outbreak of SARS-CoV-2 infection was named coronavirus disease 2019 (COVID-19) by the World Health Organization (WHO). COVID-19 was declared as a pandemic by the WHO in March 2020 and spread rapidly to many countries around the world. ${ }^{[6]}$ The most common symptoms are fever, cough, shortness of breath, and organizing pneumonia characterized by bilateral infiltrates on lung imaging in COVID-19 cases. However, there is no specific clinical feature that allows COVID- 19 to be differentiated from other viral respiratory infections. In some studies from China, smell and taste disorders (anosmia and dysgeusia) have also been described as other common symptoms in patients with COVID-19..$^{[7]}$ Although studies with similar results have been conducted, it is still controversial whether these symptoms are a distinctive feature of COVID-19 in Italy. ${ }^{[8]}$
The prevalence of gastrointestinal symptoms has been reported as diarrhea in 18\% and nausea-vomiting in 13\% in various meta-analyses and acute abdomen is seen very rarely.

In the current series, patients were diagnosed with ACC as a result of the emergency acute abdomen picture, which was the main reason for presentation. The association of ACC and COVID-19 is rarely seen, and care should be taken in terms of treatment selection and planning for this patient group.

Respiratory symptoms that may be associated with COVID-19 were not detected in this patient group, but due to the COVID-19 outbreak, which has been declared as a pandemic worldwide, especially in patients over 65 years of age and with additional comorbidity, thorax CT and abdominal CT examination can be performed to evaluate possible complications (gallbladder perforation, acute pancreatitis, malignancy etc.).

Although radiology organizations and associations are against the use of thorax CT for the purpose of screening in the diagnosis of COVID-19, radiological imaging methods are widely used at the diagnosis stage and in the evaluation of complications for various reasons.

RTPCR test is the gold standard in the diagnosis of COVID-19. However, besides the limitations on the availability of this test, variables such as adequacy of sample quantity, type, transportation, and the time of the disease affect the sensitivity in clinical practice. In the current study, only half of the patients were diagnosed using the RTPCR test. The fact that the test sensitivity is not high enough and the difficulties in availability of the test are the most important reasons to increase the use of direct radiography and CT in diagnosis. Direct radiography is not sensitive and has a low diagnostic value in patients who have no significant respiratory complaints in the early period as in the current series. ${ }^{[9,10]}$

It has been specified in varying rates and it has been stated that it can be performed at low-dose or standard dose parameters at the stage of diagnosis. ${ }^{[1]}$ In COVID-19 patients, the ground-glass opacity appearance in the form of a nodule or mass located in the peripheral and posterior position, usually in the organizing pneumonia style, is typical. In addition, consolidations, linear, curvilinear, and perilobular opacities may also be present ${ }^{[12-14]}$ (Case I, Fig. 2).

In cases of suspected COVID-19 requiring urgent surgery, there is no need to wait for the definitive diagnosis of COVID-19. These patients should be included in the surgical procedure in the same way as those diagnosed with COVID-19..$^{[15]}$ In the current series, the PC procedure was performed considering COVID-19. 

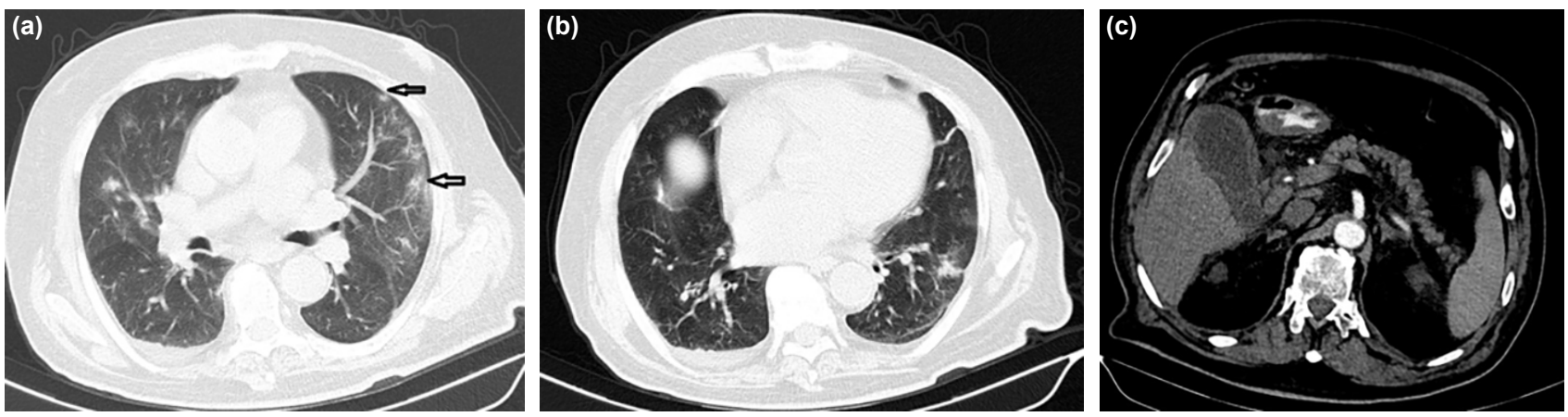

Figure 2. Case 1: Seventy-three years old, M: Thoracoabdominal CT images of patient with acute abdomen (ACC) as an early symptom; (a) The image shows the lower part of the thorax with bilateral characteristic peripheral nodular ground glass opacity (black arrows). (b) The image of the base of the left lung; peripheral consolidation with bilateral pleural effusion. (c) Abdominal CT image; distended gallbladder with wall thickening, mucosal enhancement and minimal inflammatory fat stranding.

Despite the increasing number of cases of COVID-19 worldwide, the combination of COVID-19 and ACC is very rare. In the treatment of ACC, laparoscopic cholecystectomy is the currently accepted most appropriate treatment option.

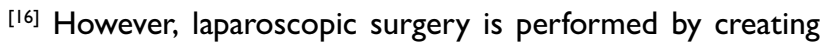
an artificial pneumoperitoneum. The ultrasonic or electrical equipment used in the process produces large amounts of surgical smoke, and the surgical team is at risk of aerosol exposure. Therefore, laparoscopic surgery and endoscopic procedures are generally not recommended in patients with diagnosed or suspected COVID-19.[17]

The majority of $A C C$ cases are seen in elderly patients and are more severe than in younger patients. ${ }^{[18]}$ Patient age of over 65 years and the presence of comorbidities (cardiovascular disease, hypertension, diabetes, chronic respiratory disease, and immune deficiency) have been identified as important risk factors for the progression of COVID-19 disease. In a study in Wuhan, China, ARDS developed in $41 \%$ of patients with COVID-19 who were hospitalized, and age $>65$ years, diabetes mellitus, and hypertension were found to be factors associated with ARDS. ${ }^{[19,20]}$ In the current series, two of the three patients who died were diagnosed with diabetes mellitus and hypertension, as well as congestive heart failure and COPD. Due to these defined comorbidities, non-surgical treatments should be applied to patients over 65 years of age with ACC and COVID-19.

There has been found to be a significant difference in morbidity and mortality between elective surgery and emergency surgery for ACC..$^{[2]}$ In a prospective study which compared patients undergoing elective and emergency cholecystectomy, it was reported that morbidity rates increased from $28 \%$ to $66 \%$ and mortality rates from $1 \%$ to $19 \%$ in emergency surgery for AC. ${ }^{[22]}$ Adding COVID-19 disease to these cases will undoubtedly increase the morbidity and mortality rates.

In addition, COVID-19 pneumonia is particularly high in the peri- and post-operative periods, and as it has a high mortality rate, any surgical treatment should be considered very carefully. The current common opinion for elective cases is to postpone the surgery as much as possible and to plan for a more appropriate time.

In the case of perforation, abscess, and sepsis together with ACC, PC should be kept in mind as an alternative treatment method. At present, local symptoms and inflammatory response can be controlled with PC. ${ }^{[23]}$ Clinical success is generally defined as a decrease in fever, leukocyte count, and pain in $72 h^{[24]}$

In the current patient group, three patients died due to COVID-19 disease. Mortality associated with PC has generally been reported to be below $1 \%$ and was not seen in this series. ${ }^{[25,26]}$ In a large-scale review by Winbladh et al.,. ${ }^{[24]}$ it was stated that up to $40 \%$ of patients undergoing PC undergo elective cholecystectomy. In the current series, medical treatments for COVID-19 were completed and elective cholecystectomy was performed in $5(27.7 \%)$ patients. The below-average rate of elective cholecystectomy can be attributed to the study group only including elderly COVID-19 patients with calculous cholecystitis.

Catheter dislocation is one of the most frequently reported complications in the PC procedure, although it is below $10 \%$ in general. ${ }^{[27]}$ Catheter dislocation occurred in two patients in the current series and the catheters were successfully replaced.

Other complications such as hemorrhage, biliary peritonitis, pneumothorax, secondary infection, and sepsis have also been reported at low rates but none of these were observed in the current series. ${ }^{[28]}$

In patients with ACC, high comorbidity, and COVID-19 diagnosed during the pandemic, PC may be a life-saving treatment procedure in emergencies, as well as an intermediate line treatment option until elective surgery after medical treatment. In addition, laparoscopic cholecystectomy experience has shown a general tendency to avoid early cholecystectomy 
in centers with low experience, and surgery should be avoided when COVID-19 disease and additional comorbidities are present in patients aged over 65 years. ${ }^{[29]}$

\section{Conclusion}

In the light of these data, PC can be applied as an alternative and first-line treatment option for high-risk elderly patients with COVID-19. In this process management, PC can also act as a bridge in transition to elective surgery.

Ethics Committee Approval: This study was approved by the ethics committee of Bakirkoy Dr Sadi Konuk Education and Research Hospital (approval number: 2020/443).

\section{Peer-review: Internally peer-reviewed.}

Authorship Contributions: Concept: Ç.Ç.; Design: Ç.Ç.; Supervision: Ç.Ç.; Resource: Ç.Ç.; Materials: Ç.Ç.; Data: Ç.Ç.; Analysis: Ç.Ç.; Literature search: Ç.Ç.; Writing: Ç.Ç.; Critical revision: Ç.Ç., H.A.K.

Conflict of Interest: None declared.

Financial Disclosure: The authors declared that this study has received no financial support.

\section{REFERENCES}

1. Lai CC, Wang CY, Wang YH, Hsueh SC, Ko WC, Hsueh PR. Global epidemiology of coronavirus disease 2019 (COVID-19): Disease incidence, daily cumulative index, mortality, and their association with country healthcare resources and economic status. Int J Antimicrob Agents 2020;55:105946. [CrossRef]

2. Kiriyama S, Kozaka K, Takada T, Strasberg SM, Pitt HA, Gabata T, et al. Tokyo Guidelines 2018: Diagnostic criteria and severity grading of acute cholangitis (with videos). J Hepatobiliary Pancreat Sci 2018;25:17-30. [CrossRef]

3. Okamoto K, Suzuki K, Takada T, Strasberg SM, Asbun HJ, Endo I, et al. Tokyo Guidelines 2018: Flowchart for the management of acute cholecystitis. J Hepatobiliary Pancreat Sci 2018;25:55-72. [CrossRef]

4. Karaca AS, Özmen MM, Uçar AD, A. Yasti C, Demirer S. COVID19'lu Hastalarda genel cerrahi ameliyat uygulamalar1. Turk J Surg 2020;36:VI-X. [CrossRef]

5. Yokoe M, Takada T, Hwang TL, Endo I, Akazawa K, Miura F, et al. Validation of TG13 severity grading in acute cholecystitis: Japan-Taiwan collaborative study for acute cholecystitis. J Hepatobiliary Pancreat Sci 2017;24:338-45. [CrossRef]

6. Park SE. Epidemiology, virology, and clinical features of severe acute respiratory syndrome -coronavirus-2 (SARS-CoV-2; Coronavirus Disease-19). Clin Exp Pediatr 2020;63:119-24. [CrossRef]

7. Wang D, Hu B, Hu C, Zhu F, Liu X, Zhang J, et al. Clinical characteristics of 138 hospitalized patients with 2019 novel coronavirus-infected pneumonia in Wuhan, China. JAMA 2020;323:1061-9. [CrossRef]

8. Onder G, Rezza G, Brusaferro S. Case-fatality rate and characteristics of patients dying in relation to COVID-19 in Italy.JAMA 2020;323:17756. [CrossRef]

9. Wu Z, McGoogan JM. Characteristics of and important lessons from the coronavirus disease 2019 (COVID-19) outbreak in China: Summary of a report of 72314 cases from the Chinese center for disease control and prevention. JAMA 2020;323:1239-42. [CrossRef]
10. Kooraki S, Hosseiny M, Myers L, Gholamrezanezhad A. Coronavirus (COVID-19) outbreak: What the department of radiology should know. J Am Coll Radiol 2020;17:447-51. [CrossRef]

11. Wong HY, Lam HY, Fong AH, Leung ST, Chin TW, Lo CS, et al. Frequency and distribution of chest radiographic findings in patients positive for COVID-19. Radiology 2020;296:E72-8. [CrossRef]

12. Society of Thoracic Radiology/American Society of Emergency Radiology COVID-19 Position Statement; 2020. Available from: https://www. acr.org/advocacyand-economics/acr-ositionstatements/recommendations-forchest-radiography-and-ct-forsuspected-covid19-infection.

13. ACR Recommendations for the use of Chest Radiography and Computed Tomography (CT) for Suspected COVID-19 Infection; 2020. Available from: https://www.acr.org/advocacyand-economics/acr-positionstatements/recommendations-forchest-radiography-and-ct-forsuspected-covid19-infection.

14. Ai T, Yang Z, Hou H, Zhan C, Chen C, Lv W, et al. Correlation of chest CT and RT-PCR testing for coronavirus disease 2019 (COVID-19) in China: A report of 1014 cases. Radiology 2020;296:E32-40. [CrossRef]

15. The ACPGBI. Urgent Intercollegiate General Surgery Guidance on COVID-19. Ireland: The Association of Coloproctology of Great Britain and Ireland; 2020.

16. Loozen CS, van Santvoort HC, van Duijvendijk P, Besselink MG, Gouma DJ, Nieuwenhuijzen GA, et al. Laparoscopic cholecystectomy versus percutaneous catheter drainage for acute cholecystitis in high risk patients (CHOCOLATE): Multicentre randomised clinical trial. BMJ 2018;363:k3965. [CrossRef]

17. American College of Surgeons. COVID-19 and Surgery. COVID-19: Elective Case Triage Guidelines for Surgical Care Online March 24; 2020.

18. Bergman S, Sourial N, Vedel I, Hanna WC, Fraser SA, Newman D, et al. Gallstone disease in the elderly: Are older patients managed differently? Surg Endosc 2011;25:55-61. [CrossRef]

19. Wu C, Chen X, Cai Y, Xia J, Zhou X, Xu S, et al. Risk factors associated with acute respiratory distress syndrome and death in patients with coronavirus disease 2019 Pneumonia in Wuhan, China. JAMA Intern Med 2020;180:934-43. [CrossRef]

20. Chen T, Wu D, Chen H, Yan W, Yang D, Chen G, et al. Clinical characteristics of 113 deceased patients with coronavirus disease 2019: Retrospective study. BMJ 2020;368:m1091. [CrossRef]

21. Donati A, Ruzzi M, Adrario E, Pelaia P, Coluzzi F, Gabbanelli V, et al. A new and feasible model for predicting operative risk. Br J Anaesth 2004;93:393-9. [CrossRef]

22. Houghton PW, Jenkinson LR, Donaldson LA. Cholecystectomy in the elderly: A prospective study. Br J Surg 1985;72:220-2. [CrossRef]

23. Griniatsos J, Petrou A, Pappas P, Revenas K, Karavokyros I, Michail OP, et al. Percutaneous cholecystostomy without interval cholecystectomy as definitive treatment of acute cholecystitis in elderly and critically ill patients. South Med J 2008;101:586-90. [CrossRef]

24. Winbladh A, Gullstrand P, Svanvik J, Sandström P. Systematic review of cholecystostomy as a treatment option in acute cholecystitis. HPB (Oxford) 2009;11:183-93. [CrossRef]

25. Tseng LJ, Tsai CC, Mo LR, Lin RC, Kuo JY, Chang KK, et al. Palliative percutaneous transhepatic gallbladder drainage of gallbladder empyema before laparoscopic cholecystectomy. Hepatogastroenterology 2000;47:932-6.

26. Ito K, Fujita N, Noda Y, Kobayashi G, Kimura K, Sugawara T, et al. Percutaneous cholecystostomy versus gallbladder aspiration for acute cholecystitis: A prospective randomized controlled trial. AJR Am J Roentgenol 2004;183:193-6. [CrossRef]

27. Granlund A, Karlson BM, Elvin A, Rasmussen I. Ultrasound-guided 
percutaneous cholecystostomy in high-risk surgical patients. Langenbecks Arch Surg 2001;386:212-7. [CrossRef]

28. Akhan O, Akinci D, Ozmen MN. Percutaneous cholecystostomy. Eur J Radiol 2002;43:229-36. [CrossRef]
29. Wakabayashi G, Iwashita Y, Hibi T, Takada T, Strasberg SM, Asbun HJ, et al. Tokyo Guidelines 2018: Surgical management of acute cholecystitis: Safe steps in laparoscopic cholecystectomy for acute cholecystitis (with videos). J Hepatobiliary Pancreat Sci 2018;25:73-86. [CrossRef]

\section{ORIJINAL ÇALIŞMA - ÖZET}

\section{Yeni koronavirüs (COVID-19) hastalığı olan yaşlı ve yüksek komobiditeli hastalarda akut taşlı kolesistit tedavisinde perkütan kolesistostomi}

\section{Dr. Çağlayan Çakır, ${ }^{1}$ Dr. Hamit Ahmet Kabuli}

${ }^{1}$ Sağlık Bilimleri Üniversitesi Bakırköy Dr. Sadi Konuk Eğitim ve Araştırma Hastanesi Radyoloji Anabilim Dalı, İstanbul

${ }^{2}$ Sağlık Bilimleri Üniversitesi Bakırköy Dr. Sadi Konuk Eğitim ve Araştırma Hastanesi Genel Cerrahi Anabilim Dalı, İstanbul

AMAÇ: Akut taşı kolesistit (ATK) ve COVID-19 tanılı yüksek komorbiditesi olan yaşıı hastalarda perkütan kolesistostominin (PK) etkinliğini, güvenilirliğini ve sonuçlarını gözden geçirmeyi amaçladık.

GEREÇ VE YÖNTEM: Mart 2020-Haziran 2020 tarihleri arasında ATK ve COVID-I 9 tanısı alan ve girişimsel radyoloji ünitesinde PK tedavi işlemi yapılan 65 yaş üstü hastaların verileri hastane kayıt sistemi taranarak incelendi.

BULGULAR: COVID-19 ile birlikte ATK tanısı alan toplam 18 hastaya PK işlemi yapıldı. Hastaların I4'ü (\%78) erkek ve dördü (\%22) kadın; ortalama yaş 73.4 (dağılım, 67-8I yıl). Hastaların I7'sinde (\%94) 48-72 saat içerisinde akut kolesistit ile ilişkili semptomlar gerilemiş ve klinik olarak düzelmiştir. Perkütan kolesistostomi uygulamasının başarı oranı \%।00 olup herhangi bir komplikasyon gelişmemiştir. Üç (\%।6.6) hasta işlem sonrası yoğun bakımda entübe olarak izlenmekte iken COVID- 19 ilişkili organize pnömoni ve sonrasında gelişen akut respiratuvar distres sendromu (ARDS) nedeniyle hayatını kaybetti. Hastaların I5'i (\%83.4) elektif kolesistektomi planı yapılarak taburcu edildi.

TARTIŞMA: Dünya genelinde sıklığı giderek artan COVID- 19 salgını özellikle 65 yaş üstü hastalarda ek komorbidit hastalıklardan dolayı ölümcül olabilmektedir. Bu hasta grubunda ATK tedavisinde PK, minimal invaziv ve lokal anestezi altında yapılabilir alternatif tedavi seçeneğidir. Ayrıca bu süreç yönetiminde PK elektif cerrahiye geçişte köprü görevi görebilir.

Anahtar sözcükler: Akut taşlı kolesistit; COVID-19; perkütan kolesistostomi; yüksek riskli hastalar.

Ulus Travma Acil Cerrahi Derg 2021;27(3):296-302 doi: 10.14744/tjtes.2020.23255 